\title{
Bedre informasjon - bønn fra en pårørende
}

\author{
Som pasient kan man finne seg i mye hvis man får god og grundig informasjon. Hvorfor satser ikke syke- \\ husene mer på det?
}

Høsten 2011 hørte og leste vi gjentatte ganger om lange ventetider for kreftpasienter i sykehusene, og om statsministerens løfte eller ikke løfte om behandling innen 20 virkedager. Ifølge Bergens Tidende har køen av kreftpasienter på Haukeland universitetssykehus vokst så raskt at sykehuset må utvide kapasiteten, de sliter med å oppfylle behandlingsløftet på 20 dager, og i oktober sto 50 ferdig utredede prostatakreftpasienter fremdeles uten operasjonsdato (1). Administrerende direktør Stener Kvinnsland uttalte at situasjonen er verre enn noensinne. Det er mangel på sykepleiere og kirurger, på operasjonsstuer, senge- og intensivkapasitet, og ressurser på oppvåkningen (1). I begynnelsen av desember maltes bildet enda svartere, nå for landet som helhet. Om få år står vi rett og slett i fare for å ha stor mangel på kreftleger, om ikke noe drastisk gjøres (2).

Politikerne tegner et annet bilde. Statsministeren sa i november at nå skal det bli bedre, nå kommer økte bevilgninger, 1,4 milliarder på budsjettet for 2012, målet er at åtte av ti skal få behandling innen 20 virkedager. «Vi har blant annet øremerket penger til utvidelse av røntgenkapasiteten» (3). Er det noen som tror at dette skal løse krisen?

\section{Mangel på informasjon}

For pasientene oppleves situasjonen frustrerende - selvsagt på grunn av lange ventetider, men kanskje vel så mye på grunn av mangel på informasjon. Opplysningene i Bergens Tidende var stort sett ukjente for prostatapasientene som sto i kø. Det er tankevekkende at det er mediene som informerer og ikke sykehuset selv. Vi må ha forståelse for kapasitetsproblemene helsevesenet har å stri med, men bør det ikke være et minstekrav at pasientene blir behandlet på måter som gjør lange ventetider enklere å håndtere? Et aktuelt eksempel fra en av mine nærmeste kan illustrere situasjonen. Muligens er det atypisk, men jeg er slett ikke sikker.

I begynnelsen av mars ble han henvist av fastlegen til Haraldsplass sykehus for utredning. Etter tre måneder var det hans tur, og det ble tatt biopsi. Men prøveresultatene, som var lovet innen 2-5 uker, lot vente på seg. Han tok da selv kontakt med sykehuset for å få informasjon, men det var ingen enkel prosess! Etter mye strev fikk han ansvarlig lege telefonisk i tale. Han kunne fortelle at det var funnet til dels aggressive kreftceller, og at det var rart at han ikke hadde fått brev. Men nå skulle legen på ferie. Det kom aldri noe brev. Etter å ha summet seg, fikk han kontakt med en annen lege - og kom litt videre. I samråd med Haukeland ble det bestemt at han skulle ta nye prøver for å fastslå omfanget. Denne gangen fikk han prompte svar, og operasjon på Haukeland ble bestilt omgående. Vi hadde hørt om 20-dagersgarantien og regnet med at det nå ville bli fart i sakene. Men nei. Etter et par uker tok han kontakt med innleggingskontoret og fikk vite at de nettopp hadde fått søknaden. Diverse pur-

\section{«Det er tankevekkende at det er mediene som informerer og ikke sykehuset selv»}

ringer med bønn om i det minste å få en operasjonsdato, slik at han kunne organisere aktivitetene sine i høstmånedene, førte ikke frem. Riktig nok fikk han i begynnelsen av september et standardbrev om inntil tre måneders ventetid og en siste dato for operasjon satt til 6. desember. Da ville det ha gått ni måneder siden fastlegen sendte ham til utredning, og fem måneder siden diagnosen ble stilt. Heldigvis fikk han en skjelettscintigrafi som var negativ. $\mathrm{Og}$ heldigvis slapp han å vente så lenge som fryktet, det tok «bare» vel åtte måneder. Han var tydeligvis heldig, det går rykter om at ventetiden kan være atskillig lenger.

Haukelands urologiske avdeling har et godt rykte, og den medisinske behandlingen som min pårørende fikk var sikkert utmerket. Men det var til dels kaos på avdelingen, han ble utskrevet halvannet døgn etter en fem timers operasjon, uten ordentlig utskrivningssamtale, og med så å si ingen informasjon om hva han kunne forvente seg. Og trøblet kom. En telefon til sykehuset med spørsmål om hjelp, hadde ingen hensikt. Han ble henvist til legevakt og fastlege. Han fikk vite at det vil ta inntil to måneder før det foreligger svar fra patolog om eventuell spredning.

\section{Informasjon kan hjelpe}

Spørsmålene melder seg: Hvorfor skal det gå nesten to uker fra operasjonssøknad blir sendt til den blir registrert, all den tid Haraldsplass og Haukeland ligger vegg i vegg? Hvorfor går politikerne ut med en garanti på 20 dager for behandling av alvorlige diagnoser, når det altså kan gå månedsvis fra diagnose er stilt til behandling påbegynnes? Det kan vel ikke bety annet enn at de politisk og de medisinsk ansvarlige lever i atskilte verdener? Sett utenfra virker debatten om disse spørsmålene fastlåst, og pasientene blir stadig mer forvirret og fortvilet. Politikerne anklages for vankelmodighet, inkompetanse og bevilgningsvegring, delvis med rette. Men er det hele bildet? Kan sykehusene selv bidra med noe som ikke koster all verden av tid og penger? Jeg er sikker på at mange ventende pasienter ville få det bedre om de fikk mer individuelt tilpasset informasjon. Fremfor alt er det viktig tidligst mulig å fastsette operasjonsdato, selv om den altså skulle ligge et stykke frem i tid. Bare det vil få pasienten til å føle seg ivaretatt og gjøre det enklere å organisere sitt eget og familiens liv. Dernest er det viktig å gi pasienten grundig informasjon ved utskrivning, skriftlig som muntlig, om hvilke forholdsregler man må ta, hvilke komplikasjoner man kan vente seg og hvor man skal søke hjelp. Mye handler rett og slett om informasjon. Forbedringspotensialet er stort.

\section{Aina Schiøtz}

aina.schiotz@isf.uib.no

Institutt for samfunnsmedisinske fag Universitetet i Bergen

Aina Schiøtz (f. 1947) er dr.philos., historiker og professor i medisinsk historie.

Ingen oppgitte interessekonflikter.

Litteratur

1. Rugland I. Må bryte kreftgaranti. Bergens Tidende 14.10.2011.

2. Frykter kreftlegemangel. Dagsavisen 7.12.2011. www.dagsavisen.no/innenriks/article524575.ece (12.12.2011).

3. Hallgren A. Kreftleger slakter Stoltenbergs kreftløfte. TV2 7.11.2011. www.tv2.no/nyheter/ innenriks/politikk/kreftleger-slakterstoltenbergs-kreftloefte-3626704.html (12.12.2011).

Mottatt 12.12. 2011 og godkjent 22.12. 2011. Medisinsk redaktør Erlend Hem. 